Winter 2014

\title{
Competition Law Reform in Turkey: Actors, Networks, Translations
}

\section{Ziya Umut Turem}

Atatirk Institute for Modern Turkish History, mehmet.yercil@boun.edu.tr

Follow this and additional works at: https://www.repository.law.indiana.edu/ijgls

Part of the Comparative and Foreign Law Commons, and the International Law Commons

\section{Recommended Citation}

Turem, Ziya Umut (2014) "Competition Law Reform in Turkey: Actors, Networks, Translations," Indiana Journal of Global Legal Studies: Vol. 21 : Iss. 1 , Article 7.

Available at: https://www.repository.law.indiana.edu/ijgls/vol21/iss1/7

This Symposium is brought to you for free and open access by the Law School Journals at Digital Repository @ Maurer Law. It has been accepted for inclusion in Indiana Journal of Global Legal Studies by an authorized editor of Digital Repository @ Maurer Law. For more information, please contact rvaughan@indiana.edu.

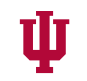

JEROME HALL LAW LIBRARY

$$
\text { INDIANA UNIVERSITY }
$$

Maurer School of Law
Bloomingeton 


\title{
Competition Law Reform in Turkey: Actors, Networks, Translations
}

\author{
ZIYA UMUT TÜREM*
}

\begin{abstract}
This article explains the shift from an initially European-oriented and politically motivated competition law, toward a U.S. style and aspiringly apolitical competition regime in Turkey. Translation is used as an analytic to capture the complex processes of such a shift. The article argues that this shift can be explained first by the broad turn toward the U.S. as a source of state expertise and knowledge production in the context of the Cold War. This broad historical dynamic could only be activated, however, by the emergence of a critical mass of policy entrepreneurs and state officials shifting the momentum of policy making away from national developmentalism toward neoliberalism. Such a critical juncture, formed essentially by a generational shift, has been decisive in changing the character of competition law regime in Turkey. A new generation of bureaucrats ended up translating competition in a way that furthers their political goals. This process has contributed to the strengthening of a certain type of competition law regime or network globally.
\end{abstract}

\section{INTRODUCTION}

On December 7, 1994, the Turkish Grand National Assembly passed the Law on the Protection of Competition (No. 4054) at the initiation of

* Atatürk Institute for Modern Turkish History, Boğaziçi University. The author wishes to thank the participants at the conference "Regulatory Translations: Expertise and Affect in Global Legal Fields" (Istanbul, May 16-18, 2013), organized by Boğaziçi University, Indiana Journal of Global Legal Studies, and Rice University, for helpful comments on this paper; Andrea Ballestero, for her thorough reading and helpful suggestions; and editors of the Indiana Journal of Global Legal Studies, Jia Li in particular, also deserve special thanks.

Indiana Journal of Global Legal Studies Vol. 21 \#1 (Winter 2014)

(C) Indiana University Maurer School of Law 
the then governing two-party coalition government. ${ }^{1}$ The passage of the law, which has effectively created a body of competition and antitrust laws, came after two similar but failed attempts during the 1980s. Those earlier attempts were left to die in the back halls of the Turkish Congress without even being introduced to the General Assembly for a vote. The passage of the law marked the beginning of a significant episode in Turkish economic management: that of building independent expert institutions or agencies to control and regulate the neoliberal economic opening.

Two points immediately stood out: On the one hand, the law was accompanied by, and legitimized with, an explicitly "political" language; on the other, the law essentially drew its inspiration from Europe. As for the former, two key goals were expressed openly by the Minister of Industry and Commerce, who prepared and pushed for the passage of the law: First, small and medium sized enterprises would be among the key beneficiaries of this particular body of law. Second, because this law was part of an "economic democratization" package, one of its main objectives was to protect consumers. These two constituencies, small and medium-sized enterprises and consumers, former more tangible than the latter, would be the target population for the legal reform, and they are considered to be the likely beneficiaries of the law. As for the inspiration for the law: Europe, and, in particular, Germany, appeared to be the place from which Turkish bureaucrats drew inspiration when assessing what code to adopt.

From the moment the law was set in motion by the establishment of the Turkish Competition Authority (TCA) in 1997, things looked rather different. Analyzing the publications of the agency reveals that the political emphasis that was dominant in the legislators' discourse has been sharply silenced as the TCA started practicing its craft. Not only did the two constituencies mentioned above disappear from the field of competition law practice, but there has also been a significant insistence that competition law has to be apolitical. Similarly, despite the continuing importance of European Union case law for Turkish competition law, the intellectual inspiration has shifted toward the United States.

How can this relatively sudden shift be explained? This article is an answer to this very question first and foremost. By outlining a brief (and necessarily broad-brush) history of Turkish competition law through this question, I also explore the question of legal reform in the period of global neoliberalization. I argue that the seemingly unique Turkish case

1. Competition Authority, REKABET.GOV, http://www.rekabet.gov.tr/default.aspx?nsw $=\mathrm{e} 2 \mathrm{zD}+\mathrm{crWr} / 0=-\mathrm{H} 7 \mathrm{deC}+\mathrm{LxBl} 8=$ (last visited Feb. 4, 2014) (Turk.) (providing the online text of the competition law in Turkish and brief information on its legislative history). 
can be used as a crystallized moment through which the broader politics of the recent legal proliferation under globalization can be viewed and analyzed.

It is obvious that the competition code in Turkey, as well as in the other countries adopting such codes in the post-1980 years, has been produced in dialogue with the external world. The U.S. model and various European Union country laws have been influential in the shaping of the Turkish code, just as they have been influential in the shaping of competition regimes elsewhere. ${ }^{2}$ This process, however, is understood best not as diffusion, as it is commonly framed, or as a direct import or as a legal transplant. All these framings assume a stable, well-defined object that can move between different jurisdictions-in this case a body of competition laws. What in fact happens, I want to point out, is much more complicated, intricate, and political than the diffusion model allows for. The shift I point to in terms of the content of competition laws in Turkey will serve as an instance to view such complex politics at work.

"Translation" offers a solid yet sufficiently flexible frame to view this complexity. It offers a uniquely powerful analytic and heuristic tool to make sense of the Turkish case, as well as the broader politics of global legal reform in neoliberalism. I use the concept in three senses in this article. First, employing a broad and general meaning of the term, I start with the assumption that translation has always been a useful concept to study legal exchanges between different jurisdictions or legal fields. While literal legal translations have constituted the core of legal formations since at least the mid-nineteenth century, ${ }^{3}$ it is also possible to speak of "legal borrowing as translation" in a broader sense. Since all legal borrowing or importing implies some form of reproduction and reformation of an original, analyzing such reproduction processes as translation, or simply such translation processes, renders visible the power dynamics, deeper structural meanings, as well as discursive regularities that constitute the context in which such translations take place. ${ }^{4}$

2. See David J. Gerber, Global Competition: Laws, Markets and Globalization 121-22 (2010).

3. See Duncan Kennedy, Three Globalizations of Law and Legal Thought: 1850-2000, in THE New LAW AND ECONOMic Development: A CRITICAL APPRAISAl 19, 19 (David M. Trubek \& Alvaro Santos eds., 2006); see also Iza Hussin, Misreading and Mobility in Constitutional Texts: A Nineteenth Century Case, 21 IND. J. Global LEGAL STUD. 145, 150 (2014).

4. See James Q. Whitman, The Moral Menace of Roman Law and the Making of Commerce: Some Dutch Evidence, 105 YALE L.J. 1841, 1845-51 (1996) (explaining that translation, understood as incorporation of the whole or part of a foreign body of law, has been crucial in the history of the production of the Western legal canon; the translation, or 
In a second vein, competition laws offer a robust site in which a translation framework can be utilized beyond its relatively more traditional usages. By their nature, competition laws contain more economic analyses than other branches or subfields of law. "The increasing influence of economic discourse [on law] was particularly felt in the area of competition law," writes Ioannis Lianos. ${ }^{5}$ This influence has increased even more in the global neoliberal period. This means that not only are there translations between countries or jurisdictions, which look to one another for competition laws, but also within the law, there must constantly be translations between two disciplines and discursive universes: law and economics. ${ }^{6}$ As importantly, perhaps, the neoclassical revival of economics in the neoliberal period has depended all too heavily on mathematics in theorizing, formulizing, and ultimately explaining its object of study. "The alliance of mathematical economics and neoclassical price theory in the 1950s with the development of a mathematical proof of the general equilibrium theory still dominates the field of welfare economics." "This. means that a constant flow of translations is needed both between jurisdictions and disciplinary lines when it comes to competition laws. ${ }^{8}$

In yet a third meaning, I will follow the concept of translation as mobilized within the "actor-network" theory. ${ }^{9}$ This will constitute the essential theoretical background to this article. According to this framework, which will be explored below, particular scientific

incorporation of Roman law, or natural law in the process of modernization of legality is a case in point).

5. Ioannis Lianos, "Lost in Translation"? Towards a Theory of Economic Transplants 4 (2009) (N.Y. Univ. Sch. of Law, Jean Monnet Working Paper 08/09), available at www. JeanMonnetProgram.org.

6. See James Boyd White, Establishing Relations Between Law and Other Forms of Thought and Language 12-13 (Univ. Mich. Law Sch. Pub. Law \& Legal Theory Working Paper Series, Paper No. 113, 2008) (showing "relations between law and other forms of thought and language" have been studied before). As I examine below, however, according to White, what happens between law and economics is not "translation" per se, but an attempt by economics at erasure of the law. See id. at 14.

7. Lianos supra note 5 , at 8 .

8. It is possible to push this link further and further historicize these disciplinary translations. Economics, since the 19th century onwards, has implicitly and explicitly based itself on "natural sciences," notably physics, and later in the 20th century there has been a fair amount of translations and crossovers between "cyborg science" and economics. See generally PhiLip Mirowski, Machine Dreams: Economics Becomes a CYborg SCIENCE (2002) (explaining the crossovers between "cyborg science" and economics); Philip Mirowski, More HEat than Light: Economics as Social Physics, Physics as NATURE'S ECONOMICS (1989) (explaining the former physics connection). Nevertheless, I will not pursue these points in this article.

9. See generally BRUNO LATOUR, REASSEMBLING THE SOCIAL: AN INTRODUCTION to ACTOR-NETWORK-THEORY (2005) (providing a general outline of this body of work). 
approaches or paradigms are actor-networks. They do not become dominant or hegemonic due to their inherent explanatory power or truth capacity, but, rather, they become powerful the more they convince as many allies or actors as possible. Translation, in this context, is key in the process of adding allies to a network. Each individual, or 'group of individuals, has to translate the core of the network-the paradigm - to its own interests to become part of a network. This act of translation, while, on the one hand, extends and, by definition, strengthens the network, also alters and modifies the network itself.

With these usages in mind, I show in the following pages that competition laws and their proliferation in Turkey-and elsewhereshould be seen and analyzed as a process of translation, rather than diffusion or transplantation. More substantively, I show that the translation of competition law and economics to Turkey has started as a process that took its inspiration and sources from Europe-Germany in particular. It was a political project with explicit political goals. It is possible, after this initial start, to trace a shift toward a more U.S.-style of antitrust regulation. The explicitly political edge of Turkish competition law is silenced for a more economic expertise-oriented view of competition law. What started out as a more traditional project to mobilize law for political ends ended up being drawn to the orbit of a new style of expert politics or politics of expertise. In the process of this shift, we see a parallel shift away from Europe toward the United States. Europe, which had long been the source and inspiration of law reform for Turkey, and for semi-peripheral countries of the global political economy, has been losing its status to the United States.

My argument as to why this shift has taken place originates from within the actor-network theory's approaches, accompanied with a slight corrective from a different theoretical tradition. The shift, first and foremost, can be explained to be a result of a changing generation of bureaucrats and its understanding of state expertise. The political orientations of different actors, and the changing stakes of competition expertise, pave the way for the emergence of a new body of translators. This changes the course of competition policy from its initial beginning-a politically oriented and more European competition law regime-toward a more U.S.-style of antitrust in which economics expertise is considered key. This shift can also be seen as the mutation or adaptation of the network of competition law and economics in Turkey. In other words, by adding more allies by way of multiple translations, new actors are brought into the field of competition, and this eventually renders the competition actor-network more solid, in Turkey as well as globally. So while the shift appears as a break, it also 
offers continuity in terms of bringing in a diverse set of new allies behind the competition network.

The point where the actor-network theory fails to satisfactorily shed light on this shift concerns the broader socio-historical framework in which this shift and Turkey's overall experience with competition laws are situated. While the shift from a traditional politics-oriented competition law to a new politics of expertise may appear like a quick one, it has been in the making for quite a while. I briefly employ the insights of another major sociologist, Pierre Bourdieu, by way of his followers, particularly Yves Dezalay and Bryant Garth, ${ }^{10}$ to point to some of the weaknesses in the actor-network theory and its possible uses in explaining the global proliferation of neoliberal forms of state expertise. I argue using the Turkish case that any possible utilization of actor-network theory is very much crippled by its relative neglect of structural factors and broader socio-historical trajectories. I thus introduce very briefly the Bourdieusian framework introduced by Dezalay and Garth to complement the theoretical frame that is constructed depending on actor-network theory. More substantively, I argue that the shifting practice of competition law in a short span of time should be analyzed as part of the broader replacement of Europe by the United States as the source of knowledge and state expertise in the Post-World War II period. Combined with the maturing United States influence that began to bear its fruits in the Turkish state during the 1980 s, the generation of bureaucrats who came of age during the strong military rule in the post- 1980 period determined the course of the competition policy in the years to come.

In the next section, I elaborate briefly on the theme of translation and set this background as the theoretical lens to analyze the Turkish case. In the second section, I focus on the trajectories of competition law in Turkey and demonstrate the shift in competition policies. In the third section, I talk about why such a shift takes place in light of the theoretical work outlined in the second section. Last, I conclude.

10. See generally Yves DEZALAY \& BRYANT GaRTH, THE INTERNATIONALIZATION OF PALACE WARS: LAWYERS, ECONOMISTS, AND THE CONTEST TO TRANSFORM LATIN AMERICAN STATES (2002) (examining both the production of northern exports such as neoliberal economics and international human rights law and the way they are received south of the United States). For an elaboration on the theoretical framework of this book, and its employment of the Bourdieusian sociology, see generally YVES DEZALAY \& BRYANT GARTH, DEALING IN VIRTUE: INTERNATIONAL COMMERCLAL ARBITRATION AND THE CONSTRUCTION OF A TRANSNATIONAL LEGAL ORDER (1996). 


\section{TRANSLATING IDEAS, LAWS, AND INSTITUTIONS}

At the heart of this article lies the deceptively simple question: "how to study the proliferation of similar laws and institutions in different parts of the world under neoliberalism?" Certainly, it is possible to extend this question beyond neoliberalism and go for an even more encompassing theory of legal and economic "transplants." However, I will limit myself to the question of neoliberalism and offer a historically contextualized narrative rather than an account that depends on a systematic theorization of legal circulation.

Competition laws and their proliferation in the post-1980 period offer a robust setting through which such legal and economic circulation can be analyzed. The dominant paradigm to explain such proliferation appears to be the "diffusion" model. Accordingly, laws and institutions that appear to provide beneficial effects diffuse to other parts of the world due to their inherent correctness, appropriateness, or efficacy. If an institution works well in a context, this is considered to be the grounds for the importing of that institution to countries lacking it. There is an echo of functionalism evident in this way of thinking that renders it problematic from a social science point of view. There, too, is an equally problematic bracketing of a variety of major social and political dynamics that condition the work and efficacy of institutions in different social and political settings.

Still, the problem with the diffusionist accounts is not that they do not take into account potential failures or incompatibility of certain institutional forms with the social settings they are introduced into. Some are free from these errors. The essential problem is that the diffusion paradigm fails to describe and explain convincingly the process of institutionalization of competition, as well as broader neoliberal regulatory reforms, in different national or regional contexts by imagining or working with the assumption of stable objects like institutions or bodies of law that travel across boundaries. As Neil Brenner, Jamie Peck, and Nik Theodore put it in reference to another context:

[The] proliferation [of regulatory reorganizations] under post-1970s capitalism cannot be understood through simple 'diffusion' models. For, rather than entailing the construction of some fully formed, coherently functioning, 'regime-like' state of neoliberalism that has progressively expanded to encompass global regulatory space, the process of neoliberalization has been 
articulated unevenly across places, territories and scales. ${ }^{11}$

The so-called diffusion process, therefore, is very complicated. In fact, the object of analysis (i.e., the object that diffuses) is produced again and again in its very movement and circulation. ${ }^{12}$ So how can we make sense of and analyze this process of proliferation? Translation offers a powerful heuristic and analytical tool to explore the diverse processes of institutional (re)formation and (re)production under neoliberalism, including, but not limited to, the institutionalization of competition law regimes in various country settings.

At the broadest level, it can be argued that, with globalization, translation explodes both as a practice to connect diverse locales, peoples, and cultures, as well as an analytic to view and analyze such processes of communication and translation. In the current phase of globalization, communities, countries, and peoples in different parts of the world are certainly much better connected than in the previous decades, leading the way for more contacts and institutional and legal cross-fertilizations. ${ }^{13}$ This increasing connectivity, however, does not mean increasing similarity or a simple move toward homogeneity. On the contrary, such connectivity means (an) ever-increasing (need for) translations. Rather than thinking of the neoliberalization process as the diffusion of some originals from certain locales to others, we need to think more in terms of constant circulations-of models, prospects, and legalities-and their translation to different contexts. As Michael Cronin puts it, it is useful to think of "globalization as translation," or a series of translations. Cronin continues:

[T] he geographical spread of globalization and the extent of the penetration of the neo-liberal version-prominent in localization writing-can be overstated. . . . This is to suggest that there is no single model of globalization which is adopted willy-nilly by different nation-states but that each country or community translates elements of the global ... economy into local circumstances. The result is the nationally and regionally differentiated

11. Neil Brenner, Jamie Peck \& Nik Theodore, After Neoliberalization?, 7 GLoBaldZATIONS 327,331 (2010) (emphasis in original).

12. See, e.g., Hussin, supra note 3 , at 156 (discussing legal circulations and accompanying legal transformations).

13. For a discussion of cross-fertilization in the transnational legal contexts, see generally Antje Wiener \& Philip Liste, Lost Without Translation? Cross-Referencing and a New Global Community of Courts, 21 IND. J. GLOBAL LEGAL STUD. 263 (2014). 
experiences of globalization across the planet. Translation is not simply a by-product of globalization but is a constituent, integral part of how the phenomenon both operates and makes sense of itself. ${ }^{14}$

Connecting back to the question of global legal reform, it can be argued that the mode of legal reform becomes translation, which is carried out from a variety of sources, not just from one or two. Translation now is the mode or medium; it is the message so to speak. This wealth of translations does not mean that there are no hierarchies in the global political economy. There certainly are. However, in analytically examining legal reform, theorists should not overlook the complexity of the current situation by recourse to relatively simple frames that use global hierarchies in explaining the flow of legalities around the globe. ${ }^{15}$ At the very least, it is of key importance to recognize that "neoliberalism was not simply disseminated from West to East, but was made possible and constructed through the dialogue and exchanges that took place within [a] transnational network." ${ }^{16}$ Similarly, a focus on translation, the process that dominates any legal reform initiative today, is a requirement to understand the subject matter.

This insightful, yet broad, view of translation as an analytic can be further narrowed down and specified as it applies to the question of competition law and economics. The actor-network theory, initiated by French sociologists Bruno Latour and Michel Callon, in particular, offers significant insights. By using the concept in combination with the analytical tool of networks, Latour makes explicit use of the concept of translation to advance a new theory of society as an assemblage. ${ }^{17} \mathrm{His}$ account is particularly helpful to understand the simultaneous increases in global translations of competition law and the increasing dominance of the "science" of economics within competition law as a discipline.

14. Michael CRonin, Translation and Globalization 34 (2010).

15. For a similar point, see Andrea Ballestero, What's in a Percentage? Calculation as the Poetic Translation of Human Rights, 21 IND. J. GLOBAL LEGAL STUD. 27, 29 (2014) (suggesting that "percentages determine better targets because they translate succinct definitions of human rights into complex webs of signification, responsibility, and economic redistribution outside of human rights courts and institutions," and consequently, "that percentages can perform that translation work because the better target is not the target that is concrete, narrow, and precise").

16. Johanna Bockman \& Gil Eyal, Eastern Europe as a Laboratory for Economic Knowledge: The Transnational Roots of Neoliberalism, 108 AM. J. SoC. 310, 311 (2002).

17. See generally LATOUR, supra note 9 , at 1 (providing a brief overview of the ActorNetwork theory). 
One of Latour's main lines of inquiry is concerned with studying science and the scientific language from a sociological perspective. In an effort to go beyond the authoritative-and thus intimidating-language of science, Latour analyzes how science in particular-and expertise centered discourses (such as law) in general-gain the authority they have. He does so by trying hard to avoid the trap of accepting the authority claims as valid at face value. ${ }^{18}$ What he suggests instead is that scientific artifacts are indeed "actor-networks"; "that is, . . . network[s] composed of a set of ties and alliances between human and non human agents."19 In trying to understand the emergence, production, or persistence of an institutional form, one needs to "focus on the actual work of constructing a network and of establishing ties between statements, instrumentation, effects demonstrated in the lab, financial resources, the opinion and support of colleagues, and other such components." 20

In the case of competition laws, then, rather than trying to explain the extent and reach of competition laws with reference to their diffusion (due to their scientificity, or simply their power to better manage "the market"), one needs to look at the actors and agents who stand to gain from being part of the network of competition law people. To the extent that the "network" can recruit more actors, or to the extent, in other words, that the network can bring in more allies by plastically expanding itself, it will become more solid and end up generating and sustaining institutions.

Translation is the key concept in the actor-network theory. Accordingly, translation refers to

the methods by which an actor enrols [sic] others . . . i.e. the way in which the various actors engaged in production/innovation processes (actors whose primary interests are not necessarily the same) interpret their own objectives into each other's language so as to ensure everyone's proper participation (or the dismissal of some actors if necessary) and the continuation of the project until fulfillment. ${ }^{21}$

18. See Bruno Latour, Science in Action: How to Follow Scientists and ENGINEERS THROUGH SOCIETY 1 (1987) (discussing these points and the general Latourian framework).

19. Bockman \& Eyal, supra note 16 , at 314 .

20. Id.

21. Helene Buzelin, Unexpected Allies: How Latour's Network Theory Could Complement Bourdieusian Analyses in Translation Studies, 11 THE TRANSLATOR 193, 196 - 
Attention has to be paid not just to the human agents, but also the wealth of documentation, institutionalization, as well as the production of discourse within the network. All these different "extensions" have the effect of extending the reach of the network, making it more solid. Lastly,

[I]f a certain institutional form is reproduced and disseminated, this is in direct proportion to the amount of resources mobilized through network ties, to the strength of the ties forged, and to the capacity of interested actors to close them in a 'black box'; that is, to hide the work needed to connect together the different elements of the actor-network. ${ }^{22}$

In Latour's own words, when "a large number of elements is made to act as one ... when all the gathered resources are made to act as one unbreakable whole," the blackboxing operation is complete, and institutions get to be successfully reproduced, seeming as if it all happens naturally, due to the inherent rationality of the institution or its superiority over others. ${ }^{23}$

The creation of competition laws in Turkey can be seen as an instance of finding and recruiting new allies in this country for the "expert governance" of the economy and the ascent of neoclassical economic discourse. Through Latour's framework, though, it is essential to view the process of recruiting allies for and the strengthening of the network-in this case the network of competition law and economics. A researcher needs to be attentive to how and in what ways actors in a given national setting end up translating the network and its existence as a way to appropriate such institutionality. Conversely, of course, the power of a particular brand of competition law that has come to be globalized is connected to the actors it can bring in to participate in its own network. As we will see below, the shift in Turkey from a European type of a competition law toward a U.S.-style antitrust regime can be seen from this angle. The U.S.-style neoliberalism ended up bringing in more allies to its ranks, being produced more solidly than the European social market economy approach.

In other words, in the case of this article, competition laws and agencies are not stable models that get to be transferred from the neoliberal heartlands to the semi-peripheries; rather, they are produced

97 (2005) (internal quotations removed) (quoting MICHEL CALLON, JOHN LAW \& ARIE RIP, MAPPING THE DYNAMICS OF SCIENCE AND TECHNOLOGY xvii (1986)).

22. Bockman \& Eyal, supra note 16 , at 314 .

23. BRUNO LATOUR, supra note 18, at 131-32. 
as a model in that very act of transmission and as an effect of the network of people, authority claims, and nonhuman agents that coalesce around these laws. The rise of such neoliberal legal forms cannot, therefore, be detached from their social and political context, as they are implicated in the power relations that cross-cut and, in that very sense, connect the importing and exporting countries. In this sense, competition laws can be theorized as an actor-network. The success of this very network comes in part from adding as many allies as possible to its ranks and in part from its power to make invisible the political work that keeps it alive and well, while ascribing the success of competition laws by referring to these laws' implicit and inherent efficacy in governing. ${ }^{24}$

Following the above thread, the broad shift toward neoliberal economics and competition laws as part of this shift can be explained by utilizing the actor-network framework. Particularly, the rise of economics discipline as a route to power and the way it came to contest law as a basis for state expertise is a case in point. ${ }^{25}$ Another similar point concerns the turf wars between neoliberal economics and Keynesian economics in terms of economic management. The struggles between these camps can be analyzed by using a Latourian framework. After all, if economics is considered to be an authoritative language-an aspiring scientific discourse-an analysis of how one specific branch of economics (neoliberal or neoinstitutional) has come to win over another (old) branch (Keynesianism) offers perfect grounds for studying how certain paradigms are taken over by others. With the tools of actornetwork theory, researchers can study closely how different actors came to view the new networks (i.e., neoliberal economics) as more beneficial for their interests and how, in the process, they opened up the black box of developmentalism and Keynesian economics, as well as the law. ${ }^{26}$

24. It has to be noted, at this point, that the actor-network theory has to be utilized with care when applied to concrete settings, particularly when one wants to talk about the global proliferation of a body of laws. After all, the actor network-theory, methodologically speaking, focuses on the "micro" processes, and does so "from the inside," i.e. the theory aims to "observe how actors make their decisions and interact while still unsure of the outcome[.]" As a consequence, "explanations are no longer found in contextual 'macrolevel' or structural determinants, but in the network itself, or, more precisely, in its length and structure." Buzelin, supra note 21 , at 197.

25. In this sense, it is noteworthy to point out, once again, James Boyd White's point that economics appears too aggressively. See, e.g., Boyd White, supra note 6, at 14. It is possible to see this penetration as an example of a profession(al network) expanding its domain, and exposing law's black box, and in particular, challenging its (law's) claims to state expertise. See generally MARC ALLEN EISNER, ANTITRUST AND THE TRIUMPH OF ECONOMICS: INSTITUTIONS, EXPERTISE AND POLICY CHANGE (1991) (providing an insightful take on this professional struggle in the context of the American antitrust field).

26. See generally YUVAL P. YONAY, STRUGGLE OVER THE SOUL OF ECONOMICS (1998), 
While Latour's perspective does carry important insights as to how we can consider competition law regimes as a network, it can be further enriched and complemented by accounts that analyze the broader power dynamics and structural locations. A focus on the macro level phenomena that also emphasize contextual or socio-historical power dynamics would provide a necessary corrective to the actor-network framework, which tends to focus too much on the inside of a network with the price of neglecting some essential power dynamics.

Read this way, Latour's account can be enriched with analyses of neoliberal globalization that are inspired by the work of a "rival" French sociologist Pierre Bourdieu. ${ }^{27}$ In using Bourdieu's framework, socio-legal scholars Yves Dezalay and Bryant Garth show that the struggles to obtain and reach state power, or simply power, in the countries of the Global South and global north came to be entangled intricately in the process of globalization and neoliberalization. Accordingly, elites and experts who are aspiring to amass state/political power end up forging connections with similar groups in other country contexts, while mobilizing such connections as routes to power in their respective power fields. This way, not only do such groups create a power base for themselves, but also through the multiplication of such instances of cross-border relations globalization/the global space is produced as a reality, despite its unevenness. The strength of Dezalay and Garth's account lies in its historicity: they show a general pattern of how, in the second half of the twentieth century with the decline of Europe and the rise of the United States and the Cold War rivalry, the European influence on the states of the Global South has decreased. Earlier European influence was based essentially on the exporting of law and legal language as instruments of statehood, as well as markers of political power, from Europe to semi-peripheries of the world economy. The elites in the global semi-peripheral contexts, such as Mexico, Brazil,

for an excellent illustration of the use of a Latourian framework to explain the struggle between neoclassical and institutional economics between the two world wars.

27. These two sociologists are self-proclaimed rivals. Their rivalry originates from the fact that their epistemologies are fundamentally different, if not fully opposed. Bourdieu bases his theoretical work on a line of classical sociologists and anthropologists, emphasizes the notion of "practice," and, in the last instance, he has an "enlightenment" streak in his work (particularly in his work on science). Latour, on the other hand, aims and claims to radically alter the studying and analysis of "the social" by reassembling it without subscribing to any philosophical milestones, such as enlightenment, and by taking into account non human "agents" (such as documents, non human animals, etc.) in the making of the present. However "unlikely," the two names can be seen, and are considered, as complementary to one another on the issue of translation. For an article on this point of fusion, particularly as it relates to the sociological analysis of literary translations, see generally Buzelin, supra note 21 . For a biting critique of Latour's work by Bourdieu, see PIERRE BouRdieU, SCIENCE OF SCIENCE AND REFLEXIVTTY 29-31 (2004). 
or Argentina, used European legal education as a way to attain state power and bolster their already established power in the society. In the course of the Cold War, and particularly after the rise of the law and economics movement in the United States, the "technopols," products of U.S. universities, began to take over "the gentlemen lawyers" as the able statesmen of the global south. All the while, economics has begun to rival, if not replace, law as the essential language and tool of statehood.28

In this context, it can be argued that economics as a discipline and science has become more solid as more alliances are formed between economics-oriented civil servants/bureaucrats, university economics departments, as well as private (market) agents in different global locations, both north and south. A case in point here is the earlier set of networks crafted between the University of Chicago's Department of Economics and economics departments outside of the United States, such as Catholic University of Chile or Mexico's Autonomous Technological Institute of Mexico (ITAM). ${ }^{29}$ Similar networks, as we will see in the next section, have been crafted between the United States and Turkey in the second half of the twentieth century. Similarly, Johanna Bockman and Gil Eyal note that neoliberal connections have been in the making for quite sometime between U.S. economists and East European economists. ${ }^{30}$ In the Post-World War II context, in general, the United States has shifted from being a recipient of laws and institutional forms to being an exporter of such models. ${ }^{31}$ Through this process of shifting locales, "economics" became more important as the role of the law declined.

More to the point, the power of neoclassical and neoliberal economics within the United States has also benefited from the connections it forged with key semi-peripheral countries such as Mexico, Chile, or Turkey. The Chicago School of Economics, for instance, which had been relatively marginal in the 1960 s, used networking with semiperipheral country universities as a strategy to build up its strength

28. For the claims in this paragraph and their further elaboration, see generally DEZALAY \& GARTH, supra note 10 (exploring the role of exported American expertise and ideals in the transformation of South American state forms and economies since World War II).

29. See SARAH BABb, Managing MEXico: Economics from Nationalism to NEOLIBERALISM 126-36 (2001).

30. Bockman \& Eyal, supra note 16 , at 311.

31. See Kennedy, supra note 3 , at 24 ("The account that follows . . portrays the United States up to the 1930 s as a context of legal reception, that is, as part of the periphery or semi periphery. Legal development was heavily determined by what was happening in Germany and later France, but the original Unitedstatesean synthesis had no influence on those countries."). 
within the United States. This was made possible, of course, by the deep ideological work they carried out in these locales, particularly against the perceived communist threat. This ideological work took, on the one hand, the form of support for military juntas and definition of the contours of an economic policy for otherwise economically illiterate juntas. ${ }^{32}$ On the other hand, the "methodological individualism" that is strongly present in the work of the Chicago School made possible an arguably deeper ideological shift toward "liberal democracy" as an antidote to communism. ${ }^{33}$ Even more to the point, the specific brand of antitrust that came to dominate the United States legal sphere in the 1970 s and 1980s-the Chicago School (as opposed to "the process school")-obtained part of its power from the connections it forged and exports it made to other countries. ${ }^{34}$

While not explicitly framing the issue as one of translation, this Bourdieusian account points to the slippery politics of holding on to state power in a globalizing context and shows what kind of connections and networks tend to be successful in the so-called neoliberal era. While Dezalay and Garth's study does not try to tell the micro-level stories of the building up of networks, it shows, in a broad brush, that the neoliberal economists from the United States and their allies in the Global South have been successful in opening the black box of Keynesianism and creating a solid black box for neoliberal economics. Consequently, the study shows the latter become intellectually and materially superior to the former over the course of time. This superiority, of course, is produced through the extension of the actor network that is neoliberal economics. A full discussion of such production is beyond the scope of this essay, but in the next section, the focus on Turkey highlights how this shift took place there.

\section{THE BEgINNINGS AND EvOLUTION OF COMPETITION LAW (PRACTICE) IN TURKEY}

The Law No. 4054 on the Protection of Competition was passed on December 7, 1994, as already mentioned in the introduction. A brief

32. See generally JuAn Gabriel Valdés, Pinochet's Economists: The Chicago SCHOOL IN CHILE (1995) (providing an account of the implantation, growth, and eventual supremacy of Chicago-style, technocratic economic sciences in Chile from the mid 1950s).

33. See generally S. M. Amadae, Rationalizing CaPitalist Democracy: THe Cold WAR ORIGINS OF RATIONAL CHOICE LIBERALISM (2003) (providing an account of how rational choice theory rose from obscurity to become the intellectual bulwark of capitalist democracy).

34. See generally EISNER, supra note 25 (providing an insightful take on the encroachment of economics in the context of the American antitrust field). 
glance at the process of the making of the law is in order, however, to view the translation in a longer time frame. The law was passed by a coalition government. After eight years of a right-wing, single-party government from 1983 to 1991, the Turkish general elections led to the formation of a coalition government. In 1991, a center-right and social democratic coalition replaced the center-right and economically liberal Motherland Party (MP), which had been in power from 1983 to 1991. The senior partner in the coalition was the right-of-center True Path Party (TPP), and the junior partner was the left-of-center Social Democratic People's Party (SDPP). The Ministry of Industry and Commerce, which drafted the competition law, was controlled by the SDPP. The senior partner was hesitant to follow the lead of the junior partner in setting up a competition law regime primarily because it had closer ties with the big business community. ${ }^{35}$ The junior partner overcame this initial hesitation, or resistance, by pointing out that competition law was a necessary step to take toward the fulfillment of Turkey's obligations for the upcoming Customs Union with European Union. ${ }^{36}$

Despite this instrumental argument, the law meant more-indeed much more-to the coalition partner drafting it. According to Hurşit Güneş, the Chief Economic Advisor to the SDPP who oversaw the drafting of the law, it would be a mistake to ascribe too much weight to the Customs Union in the passage of the law. ${ }^{37}$ Before the law was passed, and in its immediate aftermath, the rationale for the passage of the law was explained in starkly political terms. According to Tahir Köse, the Minister of Trade and Industry at the time, the initial and major motivation of the Ministry and of himself in initiating a commission to prepare the Competition Law was "economic democratization." Köse argues, back in 1994 three weeks after the law was passed, that his party considered "economic democratization as a package," and competition law, in addition to the law on the protection of consumers, was one of the most important pieces of legislation in that

35. For an overview of the Turkish politics and history of elections between 1980 and 2002, see ERIC JAN ZURCHER, TURKEY: A MODERN HISTORY 278-306 (3d ed. 2004).

36. Interview with Kemal Erol, Former Competition Board member and independent lawyer, in Istanbul, Turk. (June 28, 2006) (stating that the SDPP used the Customs Union as a tool to convince the senior partner TPP to pass the law. Customs Union treaty was a free trade agreement that would include Turkey in a common customs regime with the European Union. The treaty was the natural result of an earlier agreement between Turkey and the European Union, the Ankara Agreement, signed back in 1959.).

37. See Hurşit Güneş, Türk Rekabet Yasasmu Hazrlama Güdüleri ve Uygulamasma İişkin Oneriler [The Motives for Drafting the Turkish Competition Law and Recommendations for its Practice], PERSEMBE KONFERANSLARI [THURSDAY ConfERENCES] 3, 5-6 (2000) (Turk.). 
package. ${ }^{38}$ Competition law would therefore serve the interests of "the consumer, a rather abstract, yet meaningful construct in the Turkey of the post-1980 period, which was shifting from a planned national economy to a liberalized consumer society." 39

The consumer of the SDPP was a political construct, however. Not only did it exist within a discourse of (economic) democratization, but it also constituted a continuity with the earlier emphases of the SDPP on the middle class and the ways in which the uncontrolled neoliberal opening of the 1980s hurt a bulk of Turkey's population. Accordingly, the middle class had been so hurt by the (allegedly) corrupt and vulgar economic policies of the previous single-party government of the MP that, for the SDPP, the consumer figure stood for the people at large. Thus, the goal of passing a competition law was to make sure that the people, not big corporations, would benefit from the policies of neoliberal opening in Turkey. ${ }^{40}$ So it appears that the emphasis on the consumer was the continuation of the election platform of the SDPP, which mainly ran on the basis that the previous MP government crushed the middle class. ${ }^{41}$ The goal, in other words, was to protect the people-consumers against a corrupt economic system that benefited the government as well as big corporations. The consumer figure was an abstraction but not in the same degree as in economic textbooks.

Perhaps more explicitly and concretely political about the competition laws in their initial stages are the open references to small and medium sized enterprises. On December 16, 1992, two years before the passage of the law and approximately one year after the coalition government-who later passed the law-had been formed, a symposium entitled "The Protection of Competition in Turkey and Small and

38. See Tahir Köse, Speech at the Turkish Grand National Assembly, 19th Congress, 4th Legislative Year, 63rd Session, pp. 185-86 (Dec. 28, 1994). See also Tüketiciyi Koruma Paketi [Consumer Protection Package], MILLIYET (Istanbul), Dec. 14, 1992, at 11.

39. See Korkut Boratav, TürkiYe İkTiSAT TARIHİ: 1908-2002 [TuRkish Economic HisTORY: 1908-2002] 145-169 (9th ed. 2002) (Turk.).

40. According to Erol Katurcıoğlu, an economist who aligned himself with the SDPP politically back in the 1990 s, the problem was that the previous Motherland Party government used the relatively high state involvment in the economy as a way to create wealth for a small number of companies. The so called "State Owned Enterprises" which were politically controlled, and were geared to produce intermediate goods, would keep their prices artifically low so that companies using the equipment sold by these enterprises would make healthy profits. What, indeed, was meant by economic democratization was an intervention to break this vicious (for people, yet virtuous for those companies) cycle and bring down prices for the common men. See Interview with Erol Katırcığlu, Economist, Bilgi University, in Istanbul, Turk. (Mar. 20, 2006).

41. This idiom, "crushing the middle class," was indeed used very frequently by the SDPP in its election platform, both in 1989 municipal elections and 1991 general elections for the parliament. 
Medium Sized Enterprises" was held. One of the organizers of the conference was the Turkish Foundation for Small and Medium Enterprises (TFSME). TFSME itself was, at the time, a young organization founded in 1989 to represent self-employed people as well as small and medium sized enterprises. ${ }^{42}$

Similarly, on December 16-17, 1995, the Turkish Artisans and Retailers and Small Sized Industries Research Institute organized another conference entitled "The Impact of the Law on the Protection of Competition on the Small and Medium Sized Enterprises."43 Nurkut Inan, the chair of the expert panel that had prepared the draft competition law bill, organized this conference. In fact, this research institute, and the larger organization it was part of-the Turkish Artisans and Retailers Confederation (TARC)-had close relations with the Ministry of Trade and Industry when the Ministry was controlled by the SDPP. Such a close relationship between the Confederation and Social Democrats continued in the years to come. Tahir Köse, who initiated efforts to pass a competition law as the Minister of Trade and Industry in 1992, was the chief advisor to the chairman of TARC when I interviewed him in 2006.44 Similarly, Ersen Yavuz, who was the undersecretary of Tahir Köse, was a high level advisor at the TARC. 45

Such organic links between the umbrella organization for the small and medium-sized enterprises and the general activity around them in relation to competition law suggest that the SDPP was trying to win over a constituency and wanted to use the law as a way to bolster or enhance its legitimacy among this group of business owners. After all, election day was only a year away when the law was passed. The competition law was passed on December 7, 1994, and general elections were held on December 24, 1995.

42. The proceedings from the symposium was later published by the Turkish branch of the Konrad Adenauer Foundation of Germany. See KonRAD ADENAUER STIFTUNG, TÜRKIYE'DE REKABETIN KORUNMASI VE KÜÇÜK VE ORTA ÖLÇEKLI İşLETMELER [THE PRotection of COMPETITION AND SMALl AND Medium SizEd ENTERPRISES IN TURKEy] 1 (1992).

43. REKabETIN KoRUNMASI HAKKINDA KaNUN'UN KÜÇÜK VE ORTA ÖLÇEKLİ İşLeTMELERE ETKISI [THE IMPACT OF THE LAW ON THE PROTECTION OF COMPETITION ON SMALl AND MEDIUM SIZED ENTERPRISES] (Nurkut Inan ed., 1996) (Turk.) (providing the proceedings of this conference).

44. See Interview with Tahir Köse, Minister of Trade and Indus., Turk., in Ankara, Turk. (July 17, 2006).

45. See generally REKABETIN KORUNMASI HAKKINDA KANUN'UN KüçüK VE ORTA ÖLÇEKLI İSLETMELERE ETKISİ, supra note 43 (providing the proceedings of this conference). Also in 1997, Small and Medium Sized Industrialists and Exporters Association published a book entitled The Constitution of The Free Market Economy: The Law on the Protection of Competition. This is yet another sign that the competition agency initially was thought to benefit these small and medium sized businesses. 
What is worth noting here is that this is a type of politics, a political imaginary, that is squarely at odds with the type of expert politics that is exemplified and demonstrated in the discourses of the Competition Agency career personnel writings. This point will become clearer below, but a hint here: the type of imagination in the activity of the SDPP is such that political parties bid for the support of organized groups in the society in an informal and implicitly corporatist system, as was the case with organized labor, artisans, small producers, and others. Benefits are accorded to these groups according to the deals they strike with party organizations. The "new" neoliberal politics that is to be crystallized later in the body of the competition agency flatly refuses such type of politics. Not only do competition professionals view such corporatist shadows in politics to be generating inefficiency, but also in their discourse an atomized consumer figure replaces citizens and any of their political associations. The economic space is to be cleared from any influence from such political associations.

Apart from this shifting politics, the second change that took place with regard to competition law practice concerns the inspiration and origins of the competition law. Such inspiration came essentially from Europe as the law was drafted and in its initial years. Just to give a brief sketch of such inspiration, it can be pointed out that the conference that I alluded to above- "The Protection of Competition and Small and Medium Sized Enterprises in Turkey"-was organized in part by the Konrad Adenauer Foundation, a German think tank who has offices in Turkey, two years before the passage of the law. As part of the German involvement, the chairman of the German Cartel Office at the time, Dieter Wolf, was present in the conference, and he gave a speech entitled, Social Market Economy and Competition. ${ }^{46}$ After this particular conference, several such visits from Germany and Europe took place.

This one instance was no isolated incident; the beginnings of the Turkish competition policy had European (specifically German) influences. Indeed, when a competition law was discussed in the late 1980 s, its name was "anti cartel law," 47 a direct copy from Germany, and

46. Dieter Wolf, Chairman of the German Fed. Cartel Office, Soc. Mkt. Econ. and Competition, Address at The Protection of Competition in Turkey and Small and Medium Sized Enterprises Symposium 73-88 (Dec. 16, 1992). For the initial European influence, see also Symposium, Avrupa Topluluğu Rekabet Politikaları, Hukuk Düzeni, ve Türk Rekabet Kanun Tasarısı [European Community Competition Policy, Legal Order, and the Turkish Competition Law Bill] (1993) (Turk.).

47. See Anti-Kartel Yasasi TBMM'ye Geliyor [Anti-Cartel Law Comes to the Turkish Grand National Assembly], MILLYYET DAILY, December 18, 1989, at 5. 
the agency was to be named Cartel Office. ${ }^{48}$ Despite the change in the name, the European influence was solid. Ersan Gökmen, a former Competition Board Member, who had taken part in the institutional formation of the Turkish Competition Authority, states that "they have gone around in Europe in the process of looking what types of laws are out there, and what institutional structures are there to back them up."49 "Social market economy," borrowed from the Germans, is a term frequently evoked by drafters of the law as a justification for competition law in conferences, and references to competition law as essentially a consumer friendly, social legislation abound.

Fast forward to 1997. The TCA has finally started practicing its craft. It essentially started doing two things. First, the Agency would pursue, investigate, and ultimately penalize competition violations and oversee mergers and acquisitions. Second, the Agency began to "produce knowledge" that, at its core, contains competition law and economics. With regard to the former, the opinions of the Competition Board, the executive and decision-making organ of the TCA, do not reveal a clear trajectory or jurisprudence. Looking at the past fifteen years of competition cases does not highlight an agenda that reveals a jurisprudential or strategic trajectory. In fact, Nurkut Inan, the chair of the expert panel who drafted the law back in 1994, made this point as a complaint. Without endorsing or hinting at a particular political trajectory, Inan argued, in an interview I conducted with him, that the Agency has no real "agenda." He said that it is rather swayed, or set into motion, by "complaints" most of the time. According to him, this suggested that the Agency does not have a clear direction, preference as to how to apply the law, or whether to follow a broad political trajectory or not. ${ }^{50} \mathrm{~A}$ recent interview I conducted with a competition professional, Ahmet Sazak, confirms this insight. According to him, there is no clear agenda of the Agency and its decisions, but it clearly does follow signals from the government as to what to do and who to target. ${ }^{51}$

The second major work of the Agency, producing knowledge through producing reports, expertise theses, or briefs, offers a different story. It is here that we see a major gap between the initial political goals

48. See Ergun ÖzsunaY, KaRtel HuKuku [CARTEL LAW] 338-39, (1985) (Turk.) (discussing the potential name from an earlier bill that was drafted in 1984 by the Ministry of Industry and Commerce, but later died there). This bill speaks of a cartel board ("Kartel Kurulu" in Turkish) as the executive organ of a proposed cartel office.

49. Interview with Ersan Gökmen, Turkish Competition Auth., in Ankara, Turk. (Apr. 14, 2006).

50. Interview with Nurkut İnan, Turkish Competition Auth., in Ankara, Turk. (July 11, 2006).

51. Interview with Ahmet Sazak (pseudonym), Competition Professional, in Istanbul, Turk. (Dec. 7, 2012). 
associated with the Competition Authority and the practice of the Agency itself. The career personnel, mostly economists, and to some extent lawyers, prepare such reports and theses. An analysis of these documents shows surprisingly little emphasis, if any, on the question of consumers and small and medium sized enterprises.

Take, for instance, the case of expertise theses. ${ }^{52} \mathrm{My}$ analysis of these theses between the years of 1997 and 2008 reveal that only one out of eighty-four theses in total talk substantively about small and medium enterprises. The only thesis to focus exclusively on small and medium size enterprises is entitled, Small and Medium Sized Enterprises and Competition Policy: The Place, Function and Application of the De Minimis Rule in the Competition Law. ${ }^{53}$ It is far from discussing the Turkish case in detail however, thus constituting no exception to the absence of works focusing on the small and medium sized industry in Turkey. It is about a specific rule, the de minimis rule, ${ }^{54}$ and its application in competition law. The thesis explains how the rule is applied in the European Union countries, and at the very end, it has a relatively short section on Turkey (eleven pages out of eighty). In this section, the author explains how from 1997 onward, the Competition Authority dealt with small and medium-sized enterprises

52. Career personnel start their employment in the competition agency with the title of "assistant competition expert." For three years, they work under this title and by the end of their third year, they are expected to promote to the "competition expert" level, provided their performance reviews are satisfactory. One also has to write an "expertise thesis" as a precondition for promotion. An expertise thesis is a piece of written work that focuses on an important issue in competition law and/or economics. Format-wise, expertise theses can be likened to Master's theses: They are longer than an article/or a publishable paper yet shorter than a full book or doctoral dissertation. They range between 60 pages to 140 pages, with an average of 83 pages (for the time period I analyzed). Content wise these theses could be located within disciplines of economics-industrial economics in particular-law, management or a combination of these different disciplines. See Turkish Competition Authority, REKABET.GOV, http://www.rekabet.gov.tr/default.aspx?nsw=4OfjF KjHgIhXmThhwumRUg==-H7deC+LxBI8=\&nm=102 (last accessed Feb. 5, 2014) (Turk.) (providing full texts of these expert theses); see also Turkish Competition Authority, REKABET.GOV, http://www.rekabet.gov.tr/default.aspx?nsw=SiqkAswzJcW4RweYAje1RQ= $=-\mathrm{SgKWD}+\mathrm{pQItw}=\& \mathrm{~nm}=307$ (last accessed Feb. 5, 2014) (providing English titles of these theses).

53. Kerem TOMUR, Kobiler ve REKabet Polittikasi: DeMínimis KuRALININ ReKabet HuKuKundaki yeri, İşlevi ve UYgulama Prensipleri [SMall and Medium Sized Enterprises and Competition Policy: The Place, Function and Application of the DE Minimis RULE IN THE COMPETITION LaW] (2004) (Turk.), available at http://www. rekabet.gov.tr/File/?path=ROOT/Documents/Uzmanl\%C4\%B1k+Tezi/tez55.pdf.

54. This rule exempts relatively small firms from following specific competition laws, merger guidlines, etc. If the net effect of an otherwise non competitive (and illegal) action by firms (such as merger) will be smaller than a designated percentage (usually ten percent) of the overall market share in these firms' sector of activity, then the competition authorities ignore the violation. 
through its decisions. ${ }^{55}$ The thesis ends with proposals to make more efficient and effective use of the de minimis rule in the Turkish context.

It is noteworthy that even a brief history of small and medium sized enterprises in Turkey is missing from the thesis. There is no discussion of what kind of an economic environment produced these enterprises or how they are situated vis-a-vis the larger corporations. Instead, the competition law of Turkey and the way the de minimis rule could be accommodated within this body of law is discussed as a technical matter. As part of this discussion, opinions of the Turkish Competition Board regarding small and medium sized enterprises are introduced.

Certainly, the de minimis rule itself can be considered to be friendly to, or beneficial for, small and medium-sized enterprises. After all, the rule suggests that competition agencies should ignore competition violations such as collusions or agreements between firms, if such violations take place between relatively small or medium sized players in a market. The tone of the writing, however, suggests that the reason for this rule is not necessarily the protection of the small against the big. On the contrary, the thesis frames the question as one of economic efficiency. The author suggests that "the significance and function of competition for the efficient use of resources and economic productivity is widely accepted." 56 "Increase[s] in the efficiency and productivity of small and medium sized enterprises through collusions or partnerships with each other" are of interest because such increases are "crucial for the broader economy and competition policies at large." 57

The protection of consumers is a theme that is frequently talked about in the expertise theses. The fashion in which it is talked about, however, is worlds apart from the way the notion is used by the drafters of the law. Just like small and medium-sized enterprises do not constitute a significant topic for these theses, no explicit discussion of economic democratization could be found in them. In other words, the second major political rationale that was put forward by those who initiated the bill, economic democratization, is also absent from these theses.

What is more interesting, nonetheless, is the way potential social effects of competition policy are framed and presented in these documents. Even though it may be unrealistic to expect to see a politically loaded term such as "economic democratization" in these expert theses, these theses should present a rationale and justification as to how competition laws and policies would lead to socially beneficial outcomes. The way the potential benefits of the competition laws are

55. TOMUR, supra note 53, at 60-71.

56. TOMUR, supra note 53 , at 24 .

57. Id. at 23. 
presented reveals an overly technical view of the society that imagines and advances another form of politics. Economic democratization for citizens is operationalized by replacing the "citizen" with the "consumer" in these texts. The emphasis on the beneficial effects of competition policy on certain social groups is replaced with a monolithic understanding of a "society of consumers." The general pattern is that the society is imagined as a unitary entity, which can gain, as a whole, from the implementation of competition laws. Notions such as "general welfare" or "total social welfare" are frequently used.

Hüseyin Ünlü, for instance, argues that "the protection of the competitive process [would ensure] the distribution of resources according to the demands of the society [and thus would contribute to] the general/total welfare." 58 He goes on to suggest, quoting the Preamble for the Law on the Protection of Competition, that the decrease in prices due to increased competition "would increase the welfare of consumers, thus the society as a whole." 59

Equating consumers with the society as a whole is a conceptual tool, which can be found in almost all of the theses. Tarkan Erdoğan discusses the efficiency implications of large retailers versus small shops in his 2003 thesis on the purchasing power in the retail sector. ${ }^{60}$ Throughout the thesis, Erdoğan approaches the question from the perspective of "consumer welfare." His usage suggests that consumer welfare is equated with overall societal welfare. What is further worth noting is that Erdoğan's argument that bigger retail centers are much better from an efficiency point of view goes completely against the initial idea that competition law could be a means to protect small and medium sized businesses. ${ }^{61}$

Instead, the objective of competition laws is narrowed down to the securing of efficiency. There are various other theses that explicitly spell out the goal or function of competition laws. Murat Çetinkaya, for instance, argues that "competition policy [aims] to secure economic efficiency."62 Mehmet Yanık agrees:

58. HÜSEYIN ÜNLÜ, REKABET HUKUKU SORUSTURMALARINDA TARAF KaVRAMI VE TARAFLARIN HaKLARI [THe CONCEPT OF PARTIES IN COMPETITION INVESTIGATIONS AND THEIR RIGHTS] 12-13 (2003) (Turk.).

59. Id. (emphasis added).

60. TaRkan Erdoğan, Rekabet Hukuku Açisindan Perakende Sektöründe Alim GÜcÜ [Purchasing Power in the Retall Sector from the Perspective of COMPETITION LAW] 1 (2003) (Turk.).

61. Id.

62. Murat Çetinkaya, İlgilli Pazar KaVRami ve İlgili Pazar Taniminda Kullanilan Nicel TeknikLer [The CONCEPT of RELEvant Market and the Quantitative Techniques Used in The Definition of The Relevant Market] 10 (2003) (Turk.). 
One of the most significant features of a fully competitive market is the freedom of firms to enter and exit the market. It is due to this feature that the resources are allocated and utilized efficiently. The principal goal of competition laws is to provide robust environments in which free and competitive markets could thrive. ${ }^{63}$

Ali Demiröz is more explicit and thorough in his definition:

Competition policies aim to [secure] allocative efficiency, production with the least possible costs. ... [They also] help build a competitive environment which would eventually led to an increase in societal welfare. To this end, competition laws prohibit agreements or mergers between corporations which would limit competition or abusing dominant position in a market. ${ }^{64}$

All in all, these theses suggest that the earlier political emphasis was silenced, and an overly technical understanding of the society has become dominant. It would certainly be wrong to call this new direction that the Agency has taken as "apolitical." It, indeed, is a type of politics that tries to render itself invisible. Just like the Latourian black box that aims to make sure that the politics and all the sustenance work that goes into making a particular paradigm seem smoothly functioning, this new type of expert politics similarly tries to make itself seem apolitical while at the same time being right in the heart of politics.

\section{The UNITED STATES BECOMES THE INTELLECTUAL INSPIRATION}

Similarly, a brief look at the expertise theses suggests that the intellectual inspiration for the knowledge producing function of the competition authority is tilted toward the United States. While the impact of Europe is still very much visible, particularly in the case of legal cases that are cited, the "theory" dimension takes its inspiration very much from the United States.

63. Mehmet YaniK, REKabet Hukukunun HaKim DuRUm ve Hakim DuRUmun KÖTÜYE KULLANILMASI UYGULAMALARINDA PIYASA GİRIŞ ENGELLERİ [BARRIERS TO ENTRY under the Dominant Position and ABuse of Dominant Position Practices of COMPETITION LAW] 7 (2003) (Turk.).

64. ALi DEMIRÖZ, YENI EKONOMIDE REKABET KuRALLARI [COMPETITION RULES IN THE NEW ECONOMY] 7 (2002) (Turk.). 
To give an example, the two most cited books (except for authoritative Turkish sources such as legal textbooks on competition law) in the eighty-four theses that I analyzed are Herbert Hovenkamp's Federal Antitrust Policy and Robert Bork's Antitrust Paradox. ${ }^{65}$ Hovenkamp's Federal Antitrust Policy is cited by nineteen theses out of the eighty-four. This means that more than 22 percent of the experts in the Agency have been exposed to Hovenkamp's view. Hovenkamp's work, which focuses on the United States and antitrust theory in general, is considered foundational for the post-Chicago approach to antitrust policy. Hovenkamp and E. Thomas Sullivan's Antitrust Law, Policy and Procedure: Cases, Materials, Problems is similarly used by ten theses. ${ }^{66}$ Needless to point out, even though Hovenkamp is a postChicago School academic, his views on efficiency and the primary nature of economic analysis are not much different than the views of the Chicago School of Antitrust.

Perhaps more telling is that Robert Bork's Antitrust Paradox, which is one of the essential books of the law and economics paradigm, is cited by thirteen out of eighty-four theses or 15 percent. In other words, thirteen out of eighty-four people who have written a thesis had presumably read Bork's book. This book is the defining book for the Chicago School paradigm in antitrust/competition, which stood for an almost complete belief in the invisible hand of the market as a regulator of the economy and a high level of suspicion toward state intervention in the economic sphere. In the book, Bork argues that increasing societal welfare, measured with sophisticated and abstract economic methods, should guide competition policy rather than political goals such as protecting small firms or preventing economic power to turn into political power. This is something that again shows how different the intellectual background of these theses is compared to the initial motivation behind the materialization of competition authority in Turkey, that of creating a social market economy.

As important, if not more so, as the books are the cases from the United States and the European Union jurisdictions. A brief look at the bibliographies of the theses suggests that competition cases from Europe constitute the major chunk of the writing in these theses. ${ }^{67}$

65. HERBERT HOVENKAMP, FEDERAL ANTITRUST POLICY: THE LAW OF COMPETTTION AND Its Practice (1994); Robert Bork, The AnTitrust Paradox: A POlicy at War with ITSELF (1978).

66. E. Thomas Sullivan \& Herbert hovenkamp, ANTitrust Law, Policy and PROCEDURE: CASES, MATERIALS, PROBLEMS (2d ed. 1989).

67. By cases, I mean legal cases. For the European Union these cases include competition violation cases filed with the competition agencies in the EU countries, appellate court cases in these countries regarding a decision of any competition agency. More frequently however, decisions handed down by the European Commission's 
Looking at the combined case bibliographies of eighty-four expertise theses, I found that cases from Europe are cited a total of 1,260 times. 68 This makes on average fifteen cases per thesis. There are a total of 362 references to the cases from the United States. The discrepancy between the two figures shows that the European Union laws and cases are far more important for Turkey given that Turkey has a Customs Union agreement with the European Union and that it is still trying to harmonize its laws with the Union as it has a membership prospect in the future. The theses cite Turkish cases 225 times.

Authors likely cite a lower number of cases from Turkey because the application of competition law in Turkey is rather recent. Over the years, we can expect a rise in the number of citations from Turkey, ${ }^{69}$ but, as of now, the theses have a large chunk of case discussions from the European Union and to some extent the United States. The cases, particularly from the United States and the EU countries, are not only cited, but also discussed at length as authoritative statements explaining how to apply the law on competition and how to form competition policies. While this does not mean that decisions are viewed without any criticism, ultimately the principles of competition law come from legal decisions in Europe and the United States as much as they come from theory.

Directorate on Competition (the Commission) and decisions by the European Court of Justice (as the appellate body for the Commission) are cited. For the United States, the decisions include Federal Trade Commission decisions, as well as appellate decisions by courts of appeals, or by the Supreme Court. For Turkey, these cases include Competition Board decisions regarding a violation or decisions by the Administrative Court of Appeals regarding an appeal of a Competition Board decision.

68. There, of course, are repetitions in this figure (i.e., some cases are cited multiple times in this list of 1,260 citations). What I did with the cases cited is that I basically group them all together and counted the total number. If a case is cited in more than one thesis that means it appears more than once in this total figure. Unfortunately, because the citation formats for the cases are not yet standardized, I could not see which cases are cited the most. Another point to mention here is that these figures (case citations) include all the cases from all the levels in Europe, the United States, or Turkey, as suggested in the previous footnote.

69. Indeed, if we look at the number of citations over the years between 1997 and 2008, we see an increase in the case citations from Turkey. There has been five cohorts of expertise thesis writing in this period and with the exception of the last (5th) cohort, the citations from Turkish legal system increased regularly. There are nineteen theses in the first cohort and thirteen citations to cases in Turkey, 0.68 cases per thesis. This number increases to seventy-nine cases in the second cohort, which means 2.82 cases per thesis. The per thesis case citation is 3.70 and 5.75 for the third and fourth cohorts respectively. In the fifth cohort, oddly enough, this number declines back to two cases per thesis. In any case, to be meaningful, a larger set of theses and cohorts are needed before making inferences about the time component. 
These figures on the book citations and case citations suggest that, while case law from Europe is still very much significant, the intellectual inspiration of the law has shifted toward the United States. Perhaps even more importantly, we can view these expertise theses and cited cases as actual translations in which the new actors of competition law translate the network for themselves. By selectively incorporating the history and experiences of the United States and Europe and by bringing in the knowledge produced in these locales, these new actors define their work and distinguish it from the previous generation of bureaucrats and politicians; they thus bring to life the competition network that would benefit them the most. Similarly, it is possible to see that these career personnel translate and "produce" Turkey in their expertise theses in a very specific manner: using the tools and lenses of the economics discipline, they turn Turkey into an object, a case study. In this translation, history is erased and Turkey is produced as a site commensurable to other similar country contexts. This translation is what makes the work of these experts so significant and renders such work and its baggage an alternative to the previous generation's renderings of Turkey.

\section{The Process of Translation}

How can we make sense of this shift? If there is a change from a politically motivated starting point of competition laws found in European beginnings toward a more sterile economic competition law with U.S. influences and inspiration, what explains this change?

Certainly, it can be argued that the change is due to the research methodology I employ in this article. First, to make the case for the shift, I have looked to documents originating from politicians and law drafters. Second, I have analyzed the career bureaucrats' reports and theses. Given that these two groups are, by definition, different in terms of their interests and objectives, it is not difficult to see that it can be argued why there appears to be a shift. One can say, after all, that it is only normal that politicians would emphasize political goals that they think would bring them more votes and power. Career personnel, on the other hand, are more inclined toward professionalism and expertise, which is their strong suit. And this, arguably, can explain the observed shift.

While this is partly true, the broader story is obviously more complicated, and it has to do with a variety of factors. The passage of the law in Turkey has to be analyzed as part of the opening of the black box of national developmentalism, both as an economic policy paradigm and as an overall developmental discourse. Indeed, the shift offers a 
microcosm of such opening in a short period of time. As Latour's theoretical framework demonstrates, a scientific or policy paradigm can be successful if it can open the black box of rival paradigms and show the actual political work that goes into sustaining those paradigms. Simultaneously rendering itself and the power relations it is implicated in as invisible and apolitical, a new paradigm can become dominant if it shows itself to be a harmonious, unbreakable unity that takes its power not from the amount of work that keeps it going, but from its internal correctness. In this sense, national developmentalism, particularly in the post-1980 period, was a black box that was in the process of being opened and torn apart. Not only were the interest groups that seemed to benefit from this policy paradigm exposed, but the very politics of distribution that this paradigm entailed were labeled by the alternative neoliberal paradigm as inefficient, corrupt, and out of touch with the modern world.

What is interesting in the Turkish case is that the drafters of the Turkish competition law aimed to utilize a new institutional form for their traditional goals, which were formulated from within the national developmentalist discourse. The form or the institution they chose, however, quickly became an actor network and part of a global network that produces a new type of politics. This new body of laws and the institution to oversee them, in other words, were drawn to the orbit of mainstream neoliberal hegemony in the process. This mainstream emphasized, more than anything, the hegemony of a certain type of economics as a science of governance that is very much centered in the United States.

The general framework in which this shift took place has its roots in the growing influence of the United States in the Turkish field of power in the Post-World War II period. The early Turkish Republic (1923-45) was much more involved with Europe, both in terms of politics and in terms of setting Europe (a civilization) as a model to follow. The United States' influence on the Turkish field of power has been a Post-World War II phenomenon. The United States financially helped the Turkish State via Marshall Plan as part of its policy of containing the Soviet Union and protecting the nations from an alleged communist threat. Since then, Turkey has remained in the orbit of the United States hegemony, even though there have been occasional conflicts and points of crises, such as the invasion of northern Cyprus by the Turkish army in 1974 that led to a U.S. embargo of arms to Turkey.70

However, such economic and geopolitical partnership has not resulted in a direct influence on the mechanisms of statehood in Turkey.

70. See ZURCHER, supra note 35 , at 287 . 
While engineers employed by the Turkish State were sent to the United States for postgraduate education and training programs as early as the $1950 \mathrm{~s},{ }^{71}$ regular links between the two countries in the field of education and training of state personnel started as late as the end of the 1960s. Perhaps even more importantly, the fields of law and finance have remained very much immune from U.S. influence; they remain essentially focused on Europe. Partly because the Turkish State, in its earlier years, (between the two World Wars) modeled its laws on European examples and partly because Turkish legal education was designed with German and French models in mind, legal education has remained focused on Europe until very recently (i.e., the post-2000s).

The Turkish model of economic governance was similar to those of European countries in terms of its aspiration to bring about high employment rates through state mediation of labor and capital. A welfare state model, with its own peculiarities of course, was adopted under an import substitution industrialization regime. Combined with the earlier, interwar Republican goal of modernizing the nation and the country, this policy bundle constituted national developmentalism, the policy paradigm for overall economic growth and national modernization.

This model began to be criticized heavily beginning in the late 1970s, particularly after Turkey's severe economic crisis from 1978 to 1979. To begin with, the big businesses, which had their share of benefits from the national developmentalist policy bundle, left this coalition when they perceived their profit rates going down between 1970 and 1980 at the expense of increasing worker real wages. ${ }^{72}$ More importantly for this article was the formation of a group of intellectualpolicy entrepreneurs, within and outside of the state, who aligned themselves with and helped with the construction of a rival neoliberal paradigm. These policy entrepreneurs were of high significance for the opening up of the black box of national developmentalism and the securing of the neoliberal black box, so to speak, because they engaged in extensive knowledge and information work.

71. One of the most notable examples is Süleyman Demirel, who was the prime minister of Turkey several times over the course of $1960 \mathrm{~s}$ and $70 \mathrm{~s}$, and who later served as the president of Turkish Republic between 1993 and 2000. Early in his career in the Turkish State's Directory of Water Works, he joined training programs in the United States in the early 1950 s.

72. See ERINÇ Yeldan, KÜRESELLEŞME SÜRECinde TÜRKIYE EKonOMisi [TURKISH ECONOMY IN THE PROCESS OF GLOBALIZATION] 69 (11th ed. 2005) (Turk.); see generally BORATAV, supra note 39 (providing a broader overview of the Turkish macroeconomic history); DAVID HARVEY, A BRIEF HISTORY OF NEOLIBERALISM (2005) (providing a similar argument for the United States and Britain). 
These groups of policy entrepreneurs, formed as the connection to the United States, particularly through educational links and intergovernmental agreements, started to mature and bear fruit. Turgut Özal, the author of the January 24, 1980, decisions, ${ }^{73}$ which are considered one of the most important steps in the liberalization of the Turkish economy, was a bureaucrat trained in the United States. Later, he assumed the key vice premiership role and acquired responsibility for the economy between 1980 and 1983. He then founded the Motherland Party (MP), referred to above, which ruled the country between 1983 and 1989. Lastly, he became the president and stayed in that position until his death in 1993.

Even more importantly, the Turkish State, which has long sent its bureaucrats to foreign countries for training and education purposes, shifted its preference from European countries to the United States. While legal officials have remained an exception to this tradition, any governmental agency that has to do with the management of the economy, trade, or finance, began to send its career personnel to the United States in overwhelming numbers. Data on this point is unfortunately not abundant. But based on my research in the Turkish Prime Ministry archives, I can point to a recent set of figures. For instance, the Ministry of Finance sent 166 of its career bureaucrats abroad for one or two-year Master's programs between the years 1995 and 2005. Out of the 166 personnel sent, nine went to England, two went to Belgium, and the remaining 155 went to the United States. ${ }^{74}$ Similarly, the Undersecretariat of Treasury sent 222 of its career personnel abroad mainly for one or two-year Master's or training programs between 1995 and 2007. Out of the 222 personnel sent, twenty-seven went to England, four went to Japan, three to France, one to India, one to Italy, and one to Belgium. The remaining 185 went to the United States. ${ }^{75}$ As yet another example, the Undersecretariat of Foreign Trade sent 124 of its career personnel abroad to get a one or two-year Master's degree or training. Out of the 124 personnel sent, twelve went to England, three to Russia, two went to Canada, one to Germany, one to Belgium, and one to Spain. The remaining 104 went to the United States.

More examples can be given, but the short story is that U.S. influence has increased within the Turkish State, starting from the late 1960 s, and became almost totally dominant in the post-1980 period. This has particularly been the case in the bureaucratic departments that focus on economics, economic management, and finance.

73. See YeldAN, supra note 72; BoRATAV, supra note 39 .

74. Source material collected from Prime Ministry archives (on file with the author).

75. Id. 
This turn to the United States in obtaining expertise for the Turkish State has been accompanied by an arguably deeper, yet equally influential shift. While certain key pockets of university and college educations in Turkey, such as finance and law, remained European oriented until very recently, business education, or enterprise economics, transitioned to the U.S. style starting from the mid-1950s. Heavy U.S. investment in programs that would foster U.S.-style programs for business economics in Turkey replaced the German influence that was dominant in the interwar period. "The US itself was actively involved in the transfer process through its government agencies for international aid, private foundations, and universities." 76

These earlier networks of U.S.-style business education have not initially constituted routes to state power. This is because such education was designed for the market in the first place. The relatively heavy influence of development economics as a discipline on statecraft and planning during the Post-World War II years was also crucial for why U.S. style education could not be of central importance. Lastly, because European-oriented disciplines such as law still constituted the essential routes to state power, business education has not been part of the strategy for those who would like to assume state power.

Approximately sixty years later, however, a brief look at the composition of the Turkish Competition Authority's expert staff reveals that these earlier networks have matured to bear fruit and become routes to state power. If we look at the schools and majors from which career bureaucrats in the Competition Authority have graduated, we can see that an overwhelming majority of them are from either business administration or economics departments. As of January 2013, there are a total of 132 career personnel in the Competition Agency of Turkey. Of these 132, forty are from business administration departments and thirty-four are from economics departments. Law graduates, by contrast, make up a total of twenty-four of the $132 .{ }^{77}$

So while the politicians tried to mobilize a new institutional form for their traditional style of politics, once this new form began recruiting its staff, it is filled with actors who were already within the network of the

76. Behlül Üsdiken, The French, the German and the American: Higher Education for Business in Turkey, 1883-2003, 31 NEW PERSP. ON TURKEY 5, 15 (2004); see also Behlül Üsdiken, Türkiye'de $\dot{I}_{S}$ Yapmanın ve İsletmenin Akademikleştivilmesi [The Academicization of Doing Business and Management in Turkey], 1930-1950, 58 ANKARA ÜNIVERsitesi Siyasal Bilimler Fakültesi Dergisi [Ankara Univ. Fac. of Pol. SCI. J.] 120 (2003) (Turk.).

77. See Competition Authority, REKABET.GOv, http://www.rekabet.gov.tr/File/?path=R OOT\%2fDocuments\%2fPersonel\%2b\%25c4\%25b0statistik\%2fmeslek2013.pdf (last accessed Feb. 7, 2014) (providing the educational statistics of the Competition Authority's career personnel). 
new type of politics. Not only were they graduates of recently remodeled universities and departments, but they were also determined to extend and strengthen their networks. In this sense, once the Competition Agency started its craft, the neoliberal commonsense, which had been in the process of being constructed for sometime by then found a new institutional hub for itself. This also made possible the extension of the network by way of producing knowledge and publications and thus increased the solidity of the network while trying to actively recruit more allies.

At this point, the question can be raised as to why we see the shift in the exact five-year period between the initiation of the law in 1992 and the starting of the practice of competition with the establishment of the Competition Authority in 1997. After all, the politicians who initiated the law have also been part of Turkey, which has been exposed to growing United States influence. The answer to this question has to focus on "generational politics." The political agenda that defined the initial years of the competition law has to do with the cadre or generation of people who initially translated and imported these laws to Turkey: they were politicians from the center left and junior partner of the coalition government that passed the law. The center-left politicians, who passed the law, acted with a goal to protect consumers and small and medium sized industries, essentially as a policy or election goal. Then there were the career bureaucrats whose professional socialization, at least back then, attached a modernizing angle to the importation of competition laws. Both of these groups have long been the essential institutions of continuity in the Turkish Republic. While the Social Democratic People's Party that passed the law is a direct continuation of the Republican People's Party that "founded the Republic," the bureaucracy has been closely aligned with this party as it has served as the carrier of the ambitious modernization reforms of the Turkish State. ${ }^{78}$

Both of these groups translated and articulated-or tried to do sothe emerging competition network to their interests, aspirations, and goals. The way they translated competition policy has echoed national developmentalism and modernization, the policy paradigms that these two groups have been strongly affiliated with. The bureaucrats and politicians who initiated the translation and appropriation of competition laws belonged to a generation that came of age during the high times of import substitution industrialization and the related growth and development of the Turkish economy between 1950 and

78. See generally FEROZ AHMAD, THE MAKING OF MODERN TURKEY (1993) (providing a brief history of Turkey, and its modernization process); ERIC J. ZÜRCHER, TURKEY: A MODERN HISTORY (3d ed. 2004). 
1970. Turkey, accordingly, was still to be constructed, developed, and carried forward. Given that Europe was the end point of such modernization discourse, and that these career bureaucrats saw themselves as protectors and modernizers of the Turkish nation, they took European laws as the model for the Turkish code while also praising and highlighting the social market economy among the potential end goals of the competition law imports. Basing their strategy on an implicitly corporatist framework of politics, they highlighted the importance of competition law both as a mechanism to garner votes for the politicians and also as a mechanism to help the overall middle class.

This initial moment of institutional translation was bound to change however. The generation that staffed the Competition Authority's career ranks after its establishment in 1997 was rather young and part of a different world of meanings and practices. The founders of the Competition Authority made a conscious choice to recruit from scratch all the technical and career personnel in the Competition Authority, rather than inviting state employees in different corners of state bureaucracy such as the Ministry of Finance, the Central Bank, and so forth. This meant that the oldest person in this new generation must have been born in the early 1970 s, which marked the beginning of the end of the happy days of national developmentalism. This new generation to staff the career ranks of the Competition Authority came of age after the military intervention or coup d'etat of 1980 and its heavy-handed policies of depoliticization and liberalization followed in close alignment with the United States. ${ }^{79}$ The days of national developmentalism were over by then, and the market logic began to take over already. Having come of age in such circumstances, among other things, this generation's approach to questions about Turkey, development, and the market is rather different than the previous generation. ${ }^{80}$

This generational dynamic, combined with the already existing tendencies and increased network ties with the United States, ended up shifting the Turkish competition policy from its earlier beginnings, which emphasized European origins, and more traditional form of politics. In other words, the already existing background of U.S. influence and turn to economics and business administration broadly made possible the cultivation of the Competition Agency as a neoliberal. institution with strong U.S. influences and sterile, neoliberal politics on

79. In this sense, Turkish neoliberalization is very similar to the Chilean process, which also took place under a heavy-handed authoritarian military regime.

80. See generally ÇAĞLAR KEYDER, ULuSAL KALKINMACILIĞIN İFLASI [THE BANKRUPTCY OF NATIONAL DEVELOPMENTALISM] (1993) (Turk.) (detailing the transformation of Turkey from national developmentalism to neoliberalism). 
the one hand. On the other hand, this very dynamic made the Competition Agency itself a hub for furthering the goals of this new generation of "technopols." The new breed of career bureaucrats began to cultivate the Competition Authority as a site through which the neoliberal narrative on markets, economics, and law is produced and communicated. They did this to open up a space for themselves in the field of politics and the field of state power, which had long been dominated by the more traditional bureaucratic and political elites.

From within the actor-network theory, it is indeed possible to read this shift as a result of a struggle between an old guard and new aspiring actors for state power. While that angle is certainly there, it is also possible to view this transformation as part of the growing mainstream or orthodoxy within the transnationalizing field of competition law and economics and the recruiting of more allies for this growing mainstream from Turkey. The policies that were put forward by the politicians and bureaucrats who. initiated the law started a process through which more allies could be added to the competition network. Once the process was set into motion, however, the shape of the network shifted. The pull of the U.S. model in 1997 was much stronger than in early 1990 s, due to, among many other things, the end of the Cold War. Combined with the increased influence of the United States on state expertise in Turkey, this pull conditioned the new shape of the network in this country: actors began to be much more disposed toward this new way of thinking about competition law and economics due to the obvious strength of the network.

\section{CONCLUDING REMARKS}

In the previous pages, I offered a "thick description" of a legal reform in Turkey and showed the political, social, and generational intricacies of what otherwise appears to be a legal transplantation that has been replicated in so many different parts of the world.

What can be generalized from this thick description? The answer is offered in the body of the text in bits and pieces, but I would like to offer a very brief sketch of it below.

As the quote from Cronin above suggests, ${ }^{81}$ this case study shows that globalization is by no means homogenization. Indeed, if anything, through globalization, what we realize is how distant and different countries and their institutional and social systems are. Whether such recognition of distance and difference leads the way to bridges is a question to answer over time. What we can say now is that a myriad of

81. See supra Part I. at 162. 
translations emerge as a way to render navigable and legible this mindbogglingly intricate terrain. Translation, thus, emerges as a mode of thinking and action, and globalization itself indeed becomes translation.

Similarly, at an analytical level, translation emerges as an analytic tool or heuristic to make sense of this extremely complicated landscape. While there are several ways to use translation as an analytic-and the papers in this special issue offer a wealth of such different approachesin this article, I used the concept employed mainly in the actor-network theory. Accordingly, global legal reforms as such do not exist; instead various groups of actors get together behind reforms both to construct new paradigms, or reforms, as strong actor-networks, and to beat the old, the traditional, the former. Similarly, legal transplants are by definition meaningless if there are no groups to appropriate them and become part of the network these transplants belong to. Certainly, such knowledge and disposition to become part of these networks is conditioned through broad socio-historical factors and larger dynamics of political economy. Thus, a view of translation and appropriation in the study of legal reform and its global proliferation needs to take into account these broader factors as well. 
。 